\title{
Apendektomi Yapılan Hastaların Kültür ve Antibiyotik Duyarlılıkları, Antibiyotik Seçimleri ve Klinik Duruma Etkileri
}

\section{Culture and Antimicrobial Susceptibility and Antibiotic Selection of the Patients with Appendectomy and Their Effect on Clinical Condition}

\author{
Semiha SOLAK GRASSIE'(ID), Özgür KAYA2(ID), Fatih OCAK³(IID), Saadet AKTURAN²(ID), \\ Ș. Deniz ATAKENT ${ }^{4}$ (IID)
}

\footnotetext{
${ }^{1}$ Yıldırım Beyazıt Üniversitesi Yenimahalle Eg̃itim ve Araștırma Hastanesi, İnfeksiyon Hastalıkları ve Klinik Mikrobiyoloji Klinig̃i, Ankara, Türkiye

2 Yılırım Beyazıt Üniversitesi Yenimahalle Eg̃itim ve Araștırma Hastanesi, Genel Cerrahi Klinig̃i, Ankara, Türkiye

${ }^{3}$ Yıldırım Beyazıt Üniversitesi Yenimahalle Eg̃itim ve Araștırma Hastanesi, Tıbbi Mikrobiyoloji Klinig̃i, Ankara, Türkiye

${ }^{4}$ Ufuk Üniversitesi Tıp Fakültesi, İnfeksiyon Hastalıkları ve Klinik Mikrobiyoloji Anabilim Dalı, Ankara, Türkiye
}

Makale atıfi: Solak Grassie S, Kaya Ö, Ocak F, Akturan S, Atakent ŞD. Apendektomi yapılan hastaların kültür ve antibiyotik duyarllıkları, antibiyotik seçimleri ve klinik duruma etkileri. FLORA 2020;25(2):154-60.

\section{ÖZ}

Giriş: Intraabdominal infeksiyonlar genellikle antibiyotik tedavisinin ampirik olarak başlandığı infeksiyonlardır. Artan antibiyotik direnci ampirik antibiyotik seçiminde önemlidir. Doğru antibiyotik seçiminde toplumumuzdaki mevcut direnç durumunun bilinmesi gereklidir. Güncel rehberlerde sadece antibiyotik tedavisi ile tedavi edilmesi önerilen apandisit olguları bulunmaktadır. Bu durum ampirik antibiyotik tedavi uygunluğunun önemini daha da arttırmaktadır. Bu çalışmada hastanemizde apendektomi yapılan hasta grubunda ameliyat materyalinde üreyen etken bakteriler ve direnç durumları araştırılmıştır. Sonuçlar, başlanılan ampirik antibiyotik tedavi seçimleri ve hastaların klinik durumları ile karşılaştırılmışır.

Materyal ve Metod: Hastanemizde Haziran 2015-Haziran 2017 tarihleri arasında apandisit nedeniyle opere edilen hastalardan operasyon sırasında doku örneği kültürleri alınabilmiş olanlar çalışmamıza dahil edildi. Hastaların başlanmış olan antibiyotik tedavileri, demografik özellikleri kayıt altına alındı. Operasyon sırasında alınan doku örnekleri mikrobiyoloji laboratuvarımız tarafından aerobik kültür ekimi yapılarak incelendi. Üreyen bakterilerin antibiyotik duyarlıık testleri EUCAST standartlarına uygun olarak disk difüzyon yöntemi ile çalısııldı. Vitek 2 (BioMerieux, Fransa) otomatize identifikasyon sistemi kullanılarak bakteri identifikasyonu yapıldı.

Bulgular: Toplam 90 hasta çalışmamıza dahil edilmiştir. Bu hastaların 54 (\%60.0)'ü erkekti. Ortalama yaş $29.5 \pm 9.08$ (16-51) idi. Alınmış olan kültürlerden 31 (\%34.4)'inde üreme olmamıştır. Üreme olan doku kültürlerinde en sık üreyen mikroorganizma (51/90, \%69.9) Escherichia coli idi. Genişlemiş spektrumlu beta-laktamaz (GSBL) üreten gram-negatif bakteri izole edilme oranı 17 (\%18.9) idi. On iki hastada kültürde birden fazla bakteri üremiştir. Ampirik antibiyotik tedavisi olarak 20 (\%22.2) hastaya sefazolin ve metronidazol kombinasyon tedavisi, 65 (\%72.2) hastaya ise seftriakson ve metronidazol kombinasyon tedavisi başlanmıştır. En sık başlanılan antibiyotik olan seftriaksona duyarlıık oranı \%63.4 olarak saptanmıştır.

Sonuç: Hastalardan alınan doku kültürlerinin üçte birinde bakteri üremesi saptanmadı. GSBL pozitif gram-negatif bakteri üreme oranı \%18.9 idi. Ampirik olarak başlanan antibiyotik tedavilerinin hiçbiri GSBL pozitif bakterilerde etkili değildi. Bu çalışmada hastalarımızın 
tamamında apendektomi uygulandığından etken bakterilerdeki direnç oranları, ampirik tedavi seçimleri GSBL pozitif bakteri üreyen hastalara uygun olmasa da tedavi başarısızlığı olarak klinik pratiğe yansımadı. Ancak yaygın intraabdominal infeksiyonu olan hastalarda ve sadece antibiyotik tedavisi ile tedavi edilen apandisit hastalarında uygunsuz ampirik antibiyotik seçimleri klinik tedavi başarısızlığına sebep olabilir.

Anahtar Kelimeler: Intraabdominal infeksiyonlar; Apandisit; Antibakteriyel duyarlılı

\title{
ABSTRACT \\ Culture and Antimicrobial Susceptibility and Antibiotic Selection of the Patients with Appendectomy and Their Effect on Clinical Condition
}

\author{
Semiha SOLAK GRASSIE ${ }^{1}$, Özgür KAYA², Fatih OCAK³ ${ }^{3}$ Saadet AKTURAN², Ș. Deniz ATAKENT ${ }^{4}$ \\ ${ }^{1}$ Clinic of Infectious Diseases and Clinical Microbiology, Yildirim Beyazit University Yenimahalle Training and Research Hospital, \\ Ankara, Turkey \\ ${ }^{2}$ Clinic of General Surgery, Yildirim Beyazit University Yenimahalle Training and Research Hospital, Ankara, Turkey \\ ${ }^{3}$ Clinic of Medical Microbiology, Yildirim Beyazit University Yenimahalle Training and Research Hospital, Ankara, Turkey \\ ${ }^{4}$ Department of Infectious Diseases and Clinical Microbiology, Faculty of Medicine, University of Ufuk, Ankara, Turkey
}

Introduction: Generally, intraabdominal infections are infections where antibiotic therapy is initiated empirically. Increasing antibiotic resistance is important regarding empirical antibiotic selection. Current resistance status among the causative bacteria in the community must be known to make the correct selection. In current treatment guidelines, some appendicitis patients are treated with only antibiotic therapy. In these situations, empirical treatment choices are even more important. In this study, the causative bacteria cultured from intraoperative tissue samples of acute appendicitis patients and their antimicrobial susceptibility patterns were investigated. The results were compared with empirical antimicrobial selections and clinical outcome of the patients.

Materials and Methods: Appendix tissue cultures taken intraoperatively from acute appendicitis patients between June 2015 and June 2017 in our hospital were included into the study. Antibiotic treatments and patient demographics were recorded. Aerobic cultures of the tissue samples taken during the operation were performed in our microbiology laboratory. Antibiotic susceptibility tests of the bacteria were performed by disk diffusion method, according to the EUCAST standards. Bacterial identification was done by using the Vitek 2 (BioMerieux, France) automated identification system.

Results: A total of 90 patients were included into the study. Fifty-four (60.0\%) of these patients were males, and mean age was 29.5 \pm 9.08 (16-51). Thirty-one (34.4\%) of the tissue sample cultures did not grow any bacteria. Escherichia coli was the most common, $(51 / 90,69.9 \%)$ isolated microorganism. Extended-spectrum beta-lactamase (ESBL) producing gram-negative bacterial growth rate was 17 (18.9\%). Twelve patients grew more than one bacterium in the culture. As empirical antibiotic therapy, twenty (22.2\%) patients received cefazolin and metronidazole and 65 (72.2\%) patients received ceftriaxone and metronidazole. The susceptibility rate of ceftriaxone, which was the most commonly used antibiotic, was $63.4 \%$.

Conclusion: One-third of the tissue cultures did not grow any bacteria. ESBL positive gram-negative bacteria growth rate was $18.9 \%$. Neither of the empirical treatment regimens initiated was effective for infections caused by ESBL-producing bacteria. Since all of our patients were appendectomized patients, antimicrobial resistance did not cause any clinical treatment failures although empirical treatment choices were not suitable for patients whose cultures grew ESBL positive bacteria. However, among patients with widespread intraabdominal infection and in patients who are treated conservatively only with antibiotic therapy, unsuitable empirical treatment choices may cause clinical treatment failures.

Key Words: Intraabdominal infections; Appendicitis; Antibacterial susceptibility

\section{GiRiș}

Apandisit toplumda en s1k görülen intraabdominal infeksiyonlardandır. Basit komplike olmayan formda olabildiği gibi yaygın peritonite de sebep olabilmekte cok ağır bir klinik tablo ile seyredebilmektedir $^{[1-4]}$. Genellikle primer intraabdominal infeksiyon seklinde görülüp daha önce yapilmıs cerrahi müdahaleyle ilișkili değildir. İntramural s1nırlı olan, komplike olmayan intraabdominal infeksiyon; peritoneal kaviteye yayılmıs olan, komplike intraabdominal infeksiyon seklinde siniflandırılmaktadir $[2,5]$ 
İntraabdominal infeksiyonlar genellikle ampirik antibiyotik tedavisinin bașlandığı infeksiyonlardır. Rutin uygulamada cerrahların kültür gönderme alıskanlığı olmaması nedeniyle hastanın klinik ve laboratuvar yanitı ile antibiyotik tedavi uygunluğu değerlendirilmektedir ${ }^{[5]}$. Son zamanlarda artan sayıda çalıșmalarda bazı olgularda apendektomi uygulanmasına gerek kalmadan sadece antibiyotik tedavisinin bașarılı olduğuna dair veriler bulunmaktadır $[1,5,6]$

Giderek artan antibiyotik direnci göz önüne alındığında ampirik olarak bașlanacak antibiyotik seçiminin uygunluğu önem kazanmaktadır. Primer toplumda kazanilmıs intraabdominal infeksiyonlarda en sik görülen etkenler Enterobacteriaceae ailesine ait (Escherichia coli, Klebsiella spp. gibi) olup bu bakterilerde genișlemis spektrumlu beta-laktamaz (GSBL) üretim sıklığında artıșa bağlı olarak üçüncü kușak sefalosporinlere karșı dirençte de giderek artıs görülmektedir ${ }^{[5,7]}$.

Bizim hastalarımızın tamamını olusturan apandisit hastalarının en azından bir grubunda güncel tedavi rehberlerinde sadece antibiyotik ile tedavi önerilmektedir ${ }^{[2]}$. Bu hasta grubunda ampirik antibiyotik tedavi seçiminin uygun olması için toplumumuzdaki mevcut direnc durumunun bilinmesi gereklidir. Bu calıșmada hastanemizde apendektomi yapilmak üzere opere edilen hastalardan operasyon sırasinda alınan doku örneklerinde üreyen bakteriler ve direnc durumları incelendi. Bașlanılan ampirik antibiyotik seçiminin uygunluğu araștırıldı. $\mathrm{Bu}$ sayede cerrahi düsüunülmeyen olgularda, primer intraabdominal infeksiyonlarda doğru ampirik antibiyotik seçimi yapılmasına katkıda bulunulması amaçlandi.

\section{MATERYAL ve METOD}

Hastanemizde Haziran 2015-Haziran 2017 tarihleri arasında akut apandisit tanısıyla yatıșı yapilan ve opere edilen hastalardan operasyon si- $^{-}$ rasında doku kültürleri alınabilmiș olanlar calıșmaya alınd. Hastanede yatarken tanı alan hastalar, öncesinde girișim yapılmıs hastalar, akut apandisit tanısı alıp son üç ay içerisinde intraabdominal girișim uygulanmıs olan hastalar calıșma dıșı bırakild.

Calıșma için Yıldırım Beyazıt Üniversitesi Yenimahalle Eğitim ve Araștırma Hastanesi Klinik
Araștırmalar Etik Kurulundan onay alındı (Karar no: 2015/04/01, Tarih: 08/06/2015).

Hastalara uygulanan profilaktik antibiyotikler ve operasyon sonrasında tedavi amaçl devam eden antibiyotikler kaydedildi. Hastaların demografik özellikleri, cerrahın komplike/komplike olmayan seklinde yapmıs olduğu apandisit sınıflaması, yatıs süreleri incelendi. Hastalar taburculuk sonrası ikinci, 10 . ve 21 . günlerde kontrole cağrılarak komplikasyon gelișimi ve tedavi bașarısızlığı açısından değerlendirildi.

Doku kültürleri operasyon sırasında infekte görünümlü dokulardan alınarak mikrobiyoloji laboratuvarına gönderildi. Alınmıs olan doku örnekleri mikrobiyoloji laboratuvarında koyun kanlı agar ve EMB besiyerlerine aerobik kültür ekimi yapilarak değerlendirildi. Vitek 2 (Biomerieux, France) otomatize identifikasyon sistemi kullanılarak bakteri identifikasyonu yapıldı. Üreyen bakterilerin antibiyotik duyarlıllkları EUCAST standartlarına uygun olarak disk difüzyon yöntemiyle belirlendi.

GSBL üreten bakteriler; üçüncü kușak sefalosporinler ve sefoksitin için zon capları Vitek 2 (Biomerieux, France) otomatize sistemle ölçülerek tarandı. Çift disk sinerji testi ile doğrulaması yapılarak tanımlandı. Bu amaçla Mueller-Hinton agarına ekim yapıldıktan sonra merkeze amoksisilin-klavulanik asit $(10+20 \mu \mathrm{g})$ diski yerlestirilerek, cevreye merkezden uzaklığ $25 \mathrm{~mm}$ olacak sekilde aztreonam $(30 \mu \mathrm{g})$, seftazidim $(30 \mu \mathrm{g})$ ve sefotaksim $(30 \mu \mathrm{g})$ diskleri konuldu. $35^{\circ} \mathrm{C}$ 'de 18-20 saat inkübasyondan sonra sonuçlar değerlendirildi. Antibiyotiklere ait inhibisyon zonlarının klavulanik asit diskine doğru genișlemesi veya iki inhibisyon zonu arasindaki bakteri üreyen alanda üremenin olmadığ1 bir bölgenin görülmesi durumunda GSBL pozitif olarak yorumland.

İstatistiksel analiz, SPSS 25.00 (SPSS Inch, Chicago, IL, ABD) kullanilarak yapıld. GSBL üreten bakteri üremesi, hastaların hastanede yatıs süreleri, komplike apandisit varlığı, kullanılan antibiyotik tedavisi ve hastaların demografik özellikleri arasındaki istatistiksel ilișki araștırıldı.

\section{BULGULAR}

Calıșmaya toplam 90 hasta dahil edilmiștir. Bu hastaların 54 (\%60)'ü erkekti. Calıșmaya alınan hastalarda ortalama yas $29.5 \pm 9.08$ (16-51) idi. 
Hastaların 83 (\%92.2)'ü 45 yașın altında iken, 7 (\%7.8)'si 45 yașın üstünde idi.

Alınmıș olan kültürlerin 31 (\%34.4)'inde üreme olmamıstır. Üreme olan doku kültürlerinde en sik izole edilen mikroorganizma E. coli [51 (\%69.9)] olmustur. Üreyen bakterilerin \%83.6's Enterobacteriaceae ailesine aittir. Pseudomonas aeruginosa \%6.8, Enterococcus spp. \%5.5 oranında üremiștir. On iki (\%13.3) hastada birden fazla bakteri kültürde üremiștir (Tablo 1).

GSBL pozitif gram-negatif bakteri üreme oranı 17/90 (\%18.9) olarak saptanmıstır. E. coli sușlarında GSBL pozitiflik oranı \%32.6 olarak tespit edilmiștir. Üreyen E. coli sușlarının seftriakson duyarlılığı \%63.4, siprofloksasin duyarlılığı \%80.7 olarak bulunurken, amoksisilin-klavulanik asit duyarlılığı \%73.1 oranında saptanmıștır (Tablo 2). Üreyen enterokok sușlarının tamamı ampisiline duyarlı bulunmuștur.

Hastaların 20 (\%22.2)'sine ampirik antibiyotik tedavisi olarak sefazolin ve metronidazol kombinasyonu, 65 (\%72.2)'ine seftriakson ve metronidazol kombinasyonu, 4 (\%4.4)'üne siprofloksasin ve metronidazol kombinasyonu, 1 (\%1.1)'ine de gentamisin ve metronidazol kombinasyonu bașlanmiștır.

Hastaların 26 (\%28.9)'sında komplike apandisit mevcuttu. Hastanede ortalama yatıs süresi

\begin{tabular}{lc}
$\begin{array}{l}\text { Tablo 1. Doku kültürlerinde üreyen bakteri } \\
\text { dağılımı }\end{array}$ \\
\hline Üreyen bakteri & Sayı (\%) \\
\hline Escherichia coli & $51(69.9)$ \\
Klebsiella spp. & $7(9.6)$ \\
Pseudomonas spp. & $5(6.8)$ \\
Enterococcus spp. & $4(5.5)$ \\
Diğer Enterobactericeae & $3(4.1)$ \\
Diğer Streptococcus & $3(4.1)$ \\
\hline
\end{tabular}

$1.8 \pm 1.5$ (1-9) gündü. Hastaların hiçbirisinde tedaviye yanıtsızlık ve antibiyotik tedavi değișikliği gereksinimi olmamıștır.

Yapılan analizler sonucunda hastanede yatıs süresinin komplike apandisiti olan hastalarda anlamlı olarak daha uzun olduğu $(p=0.01)$ anlașımıștır. Hastanede yatıs süresi ile kültürde üreyen bakteri türü $(p=0.28)$, kullanilan antibiyotik türü $(p=0.79)$, yas $(p=0.79)$ ve cinsiyet $(p=0.55)$ arasında anlamlı bir iliski saptanmamıstır. GSBL pozitif bakteri üremesi ile komplike apandisit varlığı $(p=0.53)$, hastaların yatıs süreleri $(p=0.09)$, yașları $(p=0.73)$ ve cinsiyetleri $(p=0.19)$ arasında da anlamlı bir ilișki saptanmamıștır.

\section{TARTIȘMA}

Apandisit sıklıkla genç erișkin yas grubunda (19-44) görülen bir hastalıktır ${ }^{[1,8]}$. Bizim hasta grubumuz da bu durumla uyumlu olup hastalar1mızın \%92.2'si 45 yas altındaydı.

Hastalardan alınan doku kültürlerinin üçte birinde üreme olmadi. Üreme olan kültürlerden en sık izole edilen bakteriler, diğer toplumdan kazanılmıs komplike ve komplike olmayan intraabdominal infeksiyonlar üzerinde yapilan calıșma sonuclarıyla benzer olarak $E$. coli ve Klebsiella spp. olarak bulunmustur ${ }^{[3-5,9,10]}$. Bazı çalısmalarda, $P$. aeruginosa \%8-10 oranında etken olarak saptanırken, çalısmamızda \%6.8 oranında olup bizim sonucumuzla benzer bașka çalıșmalar da bulunmaktadır $^{[3-5,9]}$. Bir calıșmada toplum kaynaklı intraabdominal infeksiyonlarda enterokoklarin etken olarak izole edilme oranı \%8.7'dir ${ }^{[9]}$. Toplum kaynaklı intraabdominal infeksiyonlarda enterokok suslarının tamamının Enterococcus faecalis olarak tanımlandı̆̆ı ve hepsinin ampisiline duyarlı olduğu bildirilmiștir ${ }^{[5]}$. Bizim sonuçlarımızda enterokoklar \%5.5 oranında etken olarak saptanmıs, tamamı ampisiline duyarlı olarak bulunmustur; izole edilen enterokok sușlarının tür düzeyinde tiplendirilmesi ise yapılmamıstır.

Tablo 2. Doku kültürlerinde en sık üreyen bakteri olan Escherichia coli izolatlarında antibiyotik duyarlılık durumu

\begin{tabular}{lcccccccc}
$\begin{array}{l}\text { Üreyen } \\
\text { bakteri }\end{array}$ & $\begin{array}{c}\text { Amoksisilin- } \\
\text { klavulanik asit } \\
\mathbf{n}(\%)\end{array}$ & $\begin{array}{c}\text { Seftriakson } \\
\mathbf{n}(\%)\end{array}$ & $\begin{array}{c}\text { Gentamisin } \\
\mathbf{n}(\%)\end{array}$ & $\begin{array}{c}\text { Amikasin } \\
\mathbf{n}(\%)\end{array}$ & $\begin{array}{c}\text { Siprofloksasin } \\
\mathbf{n}(\%)\end{array}$ & $\begin{array}{c}\text { Trimetoprim- } \\
\text { sülfametoksazol } \\
\mathbf{n}(\%)\end{array}$ & $\begin{array}{c}\text { Piperasilin- } \\
\text { tazobaktam } \\
\mathbf{n}(\%)\end{array}$ & $\begin{array}{c}\text { Imipenem } \\
\mathbf{n}(\%)\end{array}$ \\
\hline E. coli & $38(73.1)$ & $33(63.4)$ & $46(88.4)$ & $52(100)$ & $42(80.7)$ & $36(69.2)$ & $49(94.2)$ & $52(100)$ \\
\hline
\end{tabular}


Calıșmamıda GSBL üreten gram-negatif bakterilerin etken olarak görülme oranı \%18.9 iken, üreyen E. coli izolatlarının \%32.6'sında GSBL pozitifliği bulunmuștur. Etken E. coli izolatlarında GSBL pozitiflik oranı hastaneye yatıs öyküsü ve cerrahi girișim öyküsü bulunmayan intraabdominal infeksiyonlu hastaların dahil edildiği bir bașka çalıșmada \%9.9 olarak bizim oranımızdan oldukça düșuik olarak bulunmuștur ${ }^{[5,11,12]}$. Toplumdan kazanılmıs intraabdominal infeksiyonlarda etken olan E. coli izolatlarında GSBL pozitifliği oranını bizim sonucumuza benzer sekilde ve daha yüksek oranlarda saptayan calıșmalar da vardır ${ }^{[13]}$. Bu farklılıkların hastaların bulunduğu bölge farkları ve toplum kaynaklı intraabdominal infeksiyon ayrımının nasıl yapıldığı ile ilișkili olabileceği düșünülmektedir. GSBL pozitifliği düșük olan çalıșmada son üç ay içinde hastane yatıs öyküsü olan ve operasyon geçirmiș olan hastaların çalıșma dıșı bırakılmıs olmasının etkili olduğu düșünülmekte$\mathrm{dir}^{[5]}$. Calıșmamızda hastanede yatarken tanı alan hastalar, öncesinde girișim yapilmıs hastalar, akut apandisit tanısı alıp son üc ay içerisinde intraabdominal girișim uygulanmıs olan hastalar calıșma dıș içinde hastanede yatıs veya operasyon öyküsü sorgulanmadi. Bir calıșmada intraabdominal infeksiyonlarda etken olarak saptanan $E$. coli izolatlarinda seftriakson direnci $\% 14.5$, kinolon direnci $\% 22.2$ olarak bildirilmiștir ${ }^{[5]}$. Bizim çalıșmamızda $E$. coli sușlarında seftriakson direnci \%36.6, kinolon direnci \%19.3 olarak bulunmustur. Kinolon direncinin daha yüksek (\%30), seftriakson direncinin ise daha düsük (\%9.5) saptandığı calıșmalar da mevcuttur ${ }^{[9,12]}$. Calıșmamızda bulunan seftriakson direnci diğer calıșmalardan yüksektir. Bir calıșmada intraabdominal infeksiyon etkeni olarak saptanan E. coli sușlarında amoksisilin-klavulanik asit duyarlılı̆̆1 \%51 olarak bulunurken, bizim $E$. coli suşlarımızda amoksisilin-klavulanik asit duyarl-lığı \%73.1 olarak seftriakson duyarlılı̆̆ından daha yüksek bulunmuștur ${ }^{[5]}$.

Komplike olmayan apandisitte sadece profilaktik antibiyotik kullanımı, komplike olan apandisitte ise tedavi amaçl antibiyotik tedavisi önerilmekte$\mathrm{dir}^{[2,14]}$. Cesitli calısmalarda bu hasta grubunda en sık kullanılan profilaktik veya tedavi amaçlı antibiyotikler kinolonlar, üçüncü kușak sefalosporinler ile metronidazol kombinasyonu, amoksisilin-klavulanik asit ya da ampisilin-sulbaktam olarak bildirilmekte-

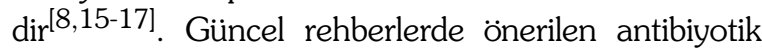
secimleri hafif ve orta siddetli intraabdominal infeksiyonlar için; ertapenem, moksifloksasin, tigesiklin ile monoterapi ya da sefazolin, sefuroksim, seftriakson, sefotaksim, levofloksasin, siprofloksasin gibi antibiyotiklerden birinin metronidazol ile kombinasyonu seklindedir ${ }^{[5,16,17]}$. Hastane bazında saptanan antibiyotik direnc oranlarında GSBL pozitif bakteri oranının \%10'un üzerinde olması durumunda ve GSBL için risk faktörleri bulunan hastalarda ampirik antibiyotik seciminin GSBL pozitif bakterileri kapsayacak sekilde yapılması önerilmektedir ${ }^{[5,11,18]}$. Bazı çlıșmalarda ise GSBL pozitif gram-negatif bakteri saptanma oranının \%20'nin üzerinde olduğu merkezlerde bile hafif siddetli infeksiyonlarda geniș spektrumlu antibiyotik kullanmanın gerekmediği vurgulanmaktadır ${ }^{[10]}$. Bu calıșmaları destekler sekilde bizim calıșmamızda hastalara bașlanan tedavilerden hiçbiri GSBL pozitif gram-negatif bakterilerde etkili olmadığı halde bu klinik sonlanıma olumsuz olarak yansımamıștır. En sık başlanılan antibiyotik olan seftriakson duyarllığının \%63.4, amoksisilin-klavulanik asit duyarlılığının \%73.1 olarak saptanması oldukça dikkat cekicidir. Literatürde bazı calısmalarda toplumda kazanılmıs intraabdominal infeksiyonların tedavisinde beta-laktamaz inhibitörleriyle kombine antibiyotiklerin kullanımı önerilmektedir ${ }^{[10,16,17]}$. Bizim calısmamızda saptanan amoksisilin-klavulanik asit duyarlllığ1 (\%73.1) bunu desteklemektedir. \%66 duyarlllı durumu ile tedavide önermeyen calıșmalar olduğu gibi toplumda sık kullanımı ve duyarlllık durumunun öngörülememesi nedeniyle ciddi infeksiyonlarda amoksisilin-klavulanik asit kullanılmamasını tavsiye eden calıșmalar da mevcuttur ${ }^{[9,11]}$.

Apandisit tanisı alan hastalarda ortalama hastanede yatıs süresi 5 ila 9 gündür ${ }^{[1,8,19]}$. Bizim hastalarımızda bu oran ortalama 1.8 gün daha kısa olarak saptanmıștır. Hastalarımızın hiçbirinde klinik tedavi bașarısızlığı görülmemis, tedavi değisikliği yapılmamıștır. Bașlanmıs olan antibiyotiklere direnç oranı yüksek olsa da bu klinik bașarısızlı̆ga neden olmamıștır. Lima ve arkadașlarının çalıșmasıyla benzer sekilde calıșmamızda hastanede yatıs süresinin uzunluğu ile komplike apandisit varlığı arasında anlamlı bir ilișki bulunmus, dirençli bak- 
teri üremesi ile yatıs süresi arasında anlamlı bir ilișki bulunmamıștır[8]. Bizim sonuclarımızda ve diğer bazı çalısmalarda dirençli bakteri üremesi ile komplike apandisit varlığı arasında anlamlı bir birliktelik gözlenmemiștir ${ }^{[19]}$. E. coli sușlarında geniș spektrumlu antibiyotiklere direnc oranının \%10-20 arasında bulunması durumunda intraoperatif kültürün rutin olarak alınması ve antibiyogram calıșlması önerilmektedir ${ }^{[5,17]}$. Ülkemizden bildirilen bir çalıșmada intraoperatif kültür gönderme oranı $\% 5.1$ olarak bulunmustur ${ }^{[20]}$. Bu oran apendektomide \%9.6 iken, intraabdominal apse durumunda oran \%94.7 seklindedir ${ }^{[5]}$. GSBL oranının en sık üretilen etken olan E. coli sușlarında \%32.6 olarak bulunmasıyla birlikte bazı intraabdominal infeksiyonlarda rutinde hic kültür alınmaması uygunsuz ampirik antibiyotik tedavisi bașlanması ve klinik bașarısızlık gözlenene kadar uygun olmayan antibiyotik tedavisi ile tedaviye devam edilmesi riskini artıracaktır.

Intraabdominal infeksiyonu olan hastaların bir kısmı sadece antibiyotik tedavisi ile tedavi edilebildiği gibi, bir kısmı da ampirik antibiyotik tedavisi bașlanıp operasyon ertelenerek elektif sartlarda yapilmaktadır ${ }^{[5,6]}$. Sadece antibiyotik tedavisi ile tedavi edilen, opere edilmeyen komplike olmayan apandisit olguları söz konusudur ${ }^{[21]}$. Bu durumda ampirik antibiyotik seçimi oldukça önemlidir. Bizim calıșmamızda hastalarımızın tamamına apendektomi uygulandığından ampirik tedavi uyumsuzluğunun klinik bașarısızlığa yol açmadığını düșünmekteyiz. Ayrıca hastalarımızın 21. günden sonra kontrole cağrılmaması da klinik bașarısılığın yeterince gözlenememesi sonucunu doğurmus olabilir. Sadece antibiyotik tedavisi ile tedavi edilmesi düșünülen apandisit hastalarında, opere edilse dahi yaygın intraabdominal infeksiyonu olan hastalarda, siddetli infeksiyonu olan, sepsisli hastalarda bașlanılan ampirik tedavinin uygun olmaması klinik bașarı durumunu bizim hasta grubumuzdan farklı olarak olumsuz etkileyebilecektir ${ }^{[22]}$.

Calıșmamızın sınırlandırıcı yanları; enterokoklarda tür tayini yapılmaması ve cerrahi alan infeksiyonları için önerilen 30. ve 90. günlerde sürveyansın yapılamamasıdır.

Sonuc olarak, intraabdominal infeksiyonu olan hastalarda intraoperatif örnek alınması ve kültürde üreyen bakterideki direnc durumunun bilinmesinin profilaktik olarak kullanılacak antibiyotik tedavisinin secimi ve ampirik antibiyotik tedavisinin bașarısı açısından önemli olduğu düșüncesindeyiz.

\section{ETIK KURUL ONAYI}

Calıșma için Yıldırım Beyazıt Üniversitesi Yenimahalle Eğitim ve Araștırma Hastanesi Klinik Araștırmalar Etik Kurulundan onay alındı (Karar no: 2015/04/01, Tarih: 08/06/2015).

\section{ÇIKAR ÇATIȘMASI}

Yazarlar bu makale ile ilgili herhangi bir çkar catıșması bildirmemișlerdir.

\section{YAZAR KATKISI}

Anafikir/Planlama: SSG, SDA

Analiz/Yorum: SSG

Veri sağlama: SA, FO, ÖK

Yazım: SSG

Gözden Geçirme ve Düzeltme: ȘDA

Onaylama: SDA

\section{KAYNAKLAR}

1. Ceresoli M, Zucchi A, Allievi N, Harbi A, Pisano M, Montori $G$, et al. Acute appendicitis: epidemiology, treatment and outcomes- analysis of 16544 consecutive cases. World J Gastrointest Surg 2016;8(10):693-9.

2. Gorter RR, Eker HH, Gorter-Stam MAW, Abis GA, Acharya $A$, Ankersmit $M$, et al. Diagnosis and management of acute appendicitis. EAES consensus development conference 2015. Surg Endosc 2016;30:4668-90.

3. Sartelli M, Catena F, Ansaloni L, Leppaniemi A, Taviloglu K, Goor HV, et al. Complicated intra-abdominal infections in Europe: a comprehensive review of the CIAO study. World I Emerg Surg 2012;7(1):36-45.

4. Sartelli M, Catena F, Ansaloni L, Moore E, Malangoni M, Velmahos $G$, et al. Complicated intra-abdominal infections in a worldwide context: an observational prospective study (CIAOW Study). World J Emerg Surg 2013;8(1):1-8.

5. Avkan-Oğuz V, Baykam N, Sökmen S, Güner R, Agalar $F$, Alp $E$, et al. Recommendations for intra-abdominal infections consensus report. Ulus Cerrahi Derg 2016;32:306-21.

6. Charalampopoulos A, Dimopoulos I, Koliakos N, Kopanakis $K$, Liakakos T, Macharias A. Non-complicated acute appendicitis in adults treated successfully by conservative treatment without recurrences. Chirurgia 2017;112:25-32.

7. Saad U, Anwar S, Kahara UZ, Siddiqui M, Saeed H. Antimicrobial susceptibility of intra-abdominal infection isolates from a tertiary care hospital in Karachi. I Ayub Med Coll Abbottabad 2016;28(3):568-71. 
8. Lima AP, Vieria FJ, Oliveira GPM, Ramos PDS, Avelino ME, Prado $F G$, et al. Clinical-epidemiological profile of acute appendicitis: retrospective analysis of 638 cases. Rev Col Bras Cir 2016;43(4):248-53.

9. Scapellato PG, Pessaca P, Corso A, Pasteran F, Rapoport $M$, Vasen $W$, et al. Aerobic etiology of acute appendicitis in adults. Multicenter study of abdominal sepsis in Arjentina. Medicina 2017;7:121-4.

10. Kurup A, Liau KH, Ren I, Lu MC, Navarro NS, Farooka MW, et al. Antibiotic management of complicated intra-abdominal infections in adults: the Asian perspective. Ann Med Sur 2014;3:85-91.

11. Sartelli M, Weber DG, Ruppe E, Bassetti M, Wright BJ, Ansaloni L, et al. Antimicrobials: a global alliance for optimizing their rational use in intra-abdominal infections (AGORA). World J Emer Surg 2016;11:33-65.

12. Lob SH, Kazmierczak KM, Badal RE, Hackel MA, Bouchillon $S K$, Biedenbach DJ, et al. Trends in susceptibility of Escherichia coli from intra-abdominal infections to ertapenem and comparators in the United States according to data from the SMART program, 2009 to 2013. Antimicrob Agents Chemother 2015;58(6):3606-10.

13. Chang YT, Coobs G, Ling T, Balaji V, Rodrigues C, Mikamo $H$, et al. Epidemiology and trends in the antibiotic susceptibilities of Gram-negative bacilli isolated from patients with intra-abdominal infections in the Asia-Pacific region, 20102013. Int / Antimicrob Agents 2017;49(6):734-9.

14. Sadraei-Moosavi SM, Nikbakhsh N, Darzi AA. Postoperative antibiotic therapy after appendectomy in patients with non-perforated appendicitis. Caspian J Intern Med 2017;8(2):104-7.

15. Xu S, Yu X, Shi D, Huang J, Gao Q, Zhang T, et al. Analysis of antibiotics selection in patients undergoing appendectomy in a Chinese tertiary care hospital. Springe Plus 2016;5:1839-43.

16. Mikamo H, Yuasa A, Wada K, Crawford B, Sugimoto N. Optimal treatment for complicated intra-abdominal infections in the era of antibiotic resistance: a systematic review and meta-analysis of the efficacy and safety of combined therapy with metronidazole. Open Forum Infect Dis 2016;3(3):ofw143. Doi: 10.1093/ofid/ofw143.
17. Solomkin JS, MzuskiJE, Bradley/S, Rodvold KA, Goldstein EJC, Baron EJ, et al. Diagnosis and management of complicated intra-abdominal infection in adults and children: guidelines by the Surgical Infection Society and the Infectious Diseases Society of America. Clin Infect Dis 2010;50:133-64.

18. Sartelli M, Catena F, Abu-Zidan FM, Ansaloni L, BiffI WL, Boermeester MA, et al. Management of intra-abdominal infections: recommendations by the WSES 2016 consensus conference. World J Emerg Surg 2017; 12:22-53.

19. Jeon $H G$, Ju HU, Kim GY, Jeong J, Kim MH, Jun JB. Bacteriology and changes in antibiotic susceptibility in adults with community-acquired perforated appendicitis. Plos One 2014;10:e111144.

20. Avkan-Oguz V, Baykam N, Korten V, Abdullayeva M, Yapar $Y$, Mulazimoglu $L$, et al. Epidemiology and antimicrobial resistance patterns of community-acquired complicated intra-abdominal infections; the data from three tertiary hospitals in Turkey. EV0338le:///Users/macbookair/Downloads/ eccmid2016_abstract_3815\%20(2).pdf (Accessed time; Sept 13, 2016)

21. Xu J, Liu YC, Adams S, Karpelowsky J. Acute uncomplicated appendicitis study: rationale and protocol for a multicentre, prospective randomized controlled non-inferiority study to evaluate the safety and effectiveness of non-operative management in children with acute uncomplicated appendicitis. BMJ 2016;6:e013299.

22. Peralta G, Lamelo M, Alvarez-Garcia P, Velasco M, Delgado A, Horcajada JP, et al. Impact of empirical treatment in extended-spectrum beta-lactamase-producing Escherichia coli and Klepsiella spp. bacteremia a multicentric cohort study. BMJ Inf Dis 2012;12:245-52.

\section{Yazıșma Adresi/Address for Correspondence}

\section{Uzm. Dr. Semiha SOLAK GRASSIE}

Yıldırım Beyazıt Üniversitesi

Yenimahalle Eğitim ve Araștırma Hastanesi, İnfeksiyon Hastalıkları ve Klinik Mikrobiyoloji Kliniŏi, Ankara-Türkiye

E-posta: semihasolak@yahoo.com 